\title{
Peningkatan Nilai Nutrisi Cangkang Siput Sebagai Sumber Mineral Pada Ransum Ayam Buras Periode Grower
}

\author{
Khalil \\ Fakultas PeternakanUniversitas Andalas Padang
}

\begin{abstract}
The objectives of the present investigation were to evaluate the effect of using shell of freshwater snails in 3 different processing forms (raw coarse ground, raw and roasted finely ground) as the major source of calcium in the diets on the performance of growing native chickens (12-24 weeks of age). Four dietary treatments were a control diet containing $2 \%$ of oyster shell meal and three others consisted of $2 \%$ of freshwater snail shell in the form raw coarse ground, raw and roasted fine ground. The diets were offered to forty growing native chicks, which were randomly divided into four groups, each amounting of 10 chickens as replication. Parameters measured included: body weight gain, feed intake, FCR, carcass weight and net return. The results showed that roasting of shell of freshwater snail prior to incorporate in the rations could significantly improve the body weigh gain, feed intake and FCR. However, the net return was negative mainly due to high feed cost. Chickens fed on diet containing raw coarse grounded shell was found the highest net return.
\end{abstract}

Keywords: freshwater snail, native chicken, mineral nutrition.

\section{Pendahuluan}

Sebagian besar tubuh siput (Lymnae $s p$ ) terdiri atas cangkang yang berpotensi untuk diguanakan sebagai bahan pakan sumber mineral, terutama kalsium (Ca). Hasil penelitian Khalil (2003) pada siput danau dan siput sawah menunjukkan bahwa rendemen cangkang mencapai $83-85 \%$ dari total bobot tubuh dan cangkang mengandung mineral kalsium (Ca) sekitar $34-35 \%$ dalam bahan kering (BK). Sedangkan kandungan mineral $\mathrm{P}$ sangat rendah, sekitar 0,05 - 0,08 \% BK (Khalil, 2003).

Selanjutnya Khalil (2004) meneliti penggunaan cangkang siput dalam ransum anak ayam buras umur 0 - 3 bulan. Hasil penelitian menunjukkan bahwa nilai nutrisi ransum yang mengandung cangkang siput sebagai sumber utama mineral $\mathrm{Ca}$ setara dengan ransum yang menggunakan tepung kulit kerang, tetapi nyata lebih rendah daripada nilai nutrisi ransum yang hanya mengandung tepung tulang sebagai sumber mineral.

Nilai nutrisi cangkang siput diharapkan dapat ditingkatkan melalui proses pengolahan, yaitu penggilingan dan pembakaran. Menurut Tillman dkk. (1998) proses pembakaran pakan sumber mineral dapat meningkatkan kosentrasi dan bioavailability mineral esessial. Berdasarkan hasil analisa yang dilakukan di Fakultas Peternakan Universitas Andalas terlihat bahwa cangkang siput mentah berbentuk grit (gilingan kasar) mengandung sekitar $35,2 \% \mathrm{Ca}$ dan dalam bentuk tepung 
mentah 31,1 \% Ca. Sedangkan tepung cangkang hasil proses pembakararan mengandung $\mathrm{Ca}$ lebih tinggi, yaitu sekitar $36,3 \%$.

Penelitian ini bertujuan untuk mengevaluasi pengaruh proses penggilingan dan pembakaran cangkang siput yang digunakan dalam ransum sebagai sumber utama mineral $\mathrm{Ca}$ terhadap performan ayam buras periode grower umur $3-6$ bulan. Sebagai pembanding (kontrol) digunakan ransum yang mengandung kulit kerang.

\section{Materi Dan Metode}

\section{Pengelompokan dan Penempatan Ternak}

Penelitian ini dilakukan di Fakultas Peternakan Universitas Andalas pada bulan Mei - Agustus 2004 dengan menggunakan ayam buras sebanyak 40 ekor yang berumur sekitar 12 minggu dengan rataan bobot $450,0 \pm 23,0$ g/ekor. Ayam dibagi ke dalam 4 kelompok, masing-masing berjumlah 10 ekor, sehingga setiap perlakukan terdiri atas 10 ulangan. Ayam ditempatkan secara acak ke dalam 40 unit kandang individu sistim batteri dengan ukuran panjang $\mathrm{x}$ lebar x tinggi $30 \times 50 \times 70 \mathrm{~cm}$. Setiap kandang dilengkapi dengan tempat makan dan tempat minum.

\section{Penyusunan dan Pemberian Ransum Perlakuan}

Sebagai perlakuan disusun 4 jenis ransum perlakuan yang berbeda bahan sumber mineralnya. Tiga ransum pertama masing - masing mengandung cangkang siput dalam bentuk grit mentah, tepung mentah dan tepung hasil pembakaran (tepung bakar). Siput diambil dari danau Maninjau, Kabupaten Agam. Proses penyiapan tepung cangkang dilakukan menurut prosedur penelitian yang telah dilakukan pada kulit pensi (Khalil, 2004). Ransum keempat mengandung kulit kerang dalam bentuk grit. Level penggunaan cangkang siput dan kulit kerang masing - masing 2,0 \%. Untuk meningkatkan kandungan $\mathrm{P}$, maka pada setiap ransum ditambahkan 0,5 $\%$ tepung tulang. Kandungan zat makanan dan energi ransum disusun berdasarkan standar kebutuhan ayam buras umur 12-22 minggu menurut rekomendasi Nawawi dan Nurrohmah (2002) dan Iskandar dkk (1991). Pada Tabel 1 disajikan komposisi bahan penyusun dan kandungan zat makanan dan energi ransum penelitian. Ransum perlakuan diberikan ad libitum dengan frekuensi dua kali sehari selama 12 minggu pemeliharaan.

\section{Parameter yang Diamati dan Diukur}

\section{Parameter yang diamati dan} diukur mencakup antara lain: pertambahan bobot badan, konsumsi dan konversi ransum, mortalitas dan morbiditas. Untuk analisa ekonomi dikumpulkan dan dihitung data biaya variabel dan penerimaan kotor.

Untuk mengetahui bobot dan persentase karkas, pada akhir penelitian ayam dipilih sebanyak 5 (lima) ekor secara acak untuk dipotong. Sebelum dipotong, ayam terpilih dipuasakan selama kurang lebih 12 jam, kemudian ditimbang untuk mendapatkan bobot potong. Selanjutnya dipisahkan bulu, kepala, kaki dan organ dalam, kemudian ditimbang, sehingga diperoleh bobot karkas. Persentase karkas dihitung dengan cara membagi bobot karkas dengan bobot potong dan dikalikan $100 \%$. 
Tabel 1. Komposisi Bahan Penyusun Dan Kandungan Zat Makanan Dan Energi Ransum Penelitian

\begin{tabular}{|c|c|c|c|c|c|}
\hline \multirow[b]{2}{*}{ No. } & \multirow[b]{2}{*}{ Nama Bahan } & \multicolumn{4}{|c|}{ Ransum Perlakuan Dengan Sumber Mineral: } \\
\hline & & $\begin{array}{l}\text { Cangkang } \\
\text { Siput Grit } \\
\text { Mentah }\end{array}$ & $\begin{array}{c}\text { Tepung } \\
\text { Cangkang } \\
\text { Siput } \\
\text { Mentah }\end{array}$ & $\begin{array}{c}\text { Tepung } \\
\text { Cangkang } \\
\text { Siput } \\
\text { Bakar }\end{array}$ & $\begin{array}{l}\text { Kulit } \\
\text { Kerang }\end{array}$ \\
\hline & - & \multicolumn{4}{|c|}{ - } \\
\hline 1. & Jangung & 37,0 & 37,0 & 37,0 & 37,0 \\
\hline 2. & Dedak padi & 44,5 & 44,5 & 44,5 & 44,5 \\
\hline 3. & Bungkil kelapa & 5,0 & 5,0 & 5,0 & 5,0 \\
\hline 4. & Bungkil kedelai & 5,5 & 5,5 & 5,5 & 5,0 \\
\hline 5. & Tepung ikan & 3,5 & $3 ; 5$ & 3,5 & 3,5 \\
\hline 6. & Minyak kelapa & 2,0 & 2,0 & 2,0 & 2,5 \\
\hline 7. & Tepung tulang & 0,5 & 0,5 & 0,5 & 0,5 \\
\hline 8. & Cangkang siput grit & 2,0 & - & - & - \\
\hline 9. & $\begin{array}{l}\text { Tepung cangkang siput } \\
\text { mentah }\end{array}$ & - & 2,0 & - & - \\
\hline 10. & $\begin{array}{l}\text { Tepung cangkang siput } \\
\text { bakar }\end{array}$ & & & 2,0 & \\
\hline 11. & Kulit kerang & - & - & - & 2,0 \\
\hline \multicolumn{6}{|c|}{ Kandungan zat makanan dan energi: } \\
\hline 1. & Protein kasar (\%) & 14,3 & 14,3 & 14,3 & 15,4 \\
\hline 2. & Serat kasar (\%) & 7,7 & 7,7 & 7,7 & 7,1 \\
\hline 3. & Kalsium (\%) & 1,44 & 1,36 & 1,45 & 0,9 \\
\hline 4. & Fospor (\%) & 0,44 & 0,45 & 0,45 & 0,5 \\
\hline 5. & Rasio Ca:P & $3,3: 1,0$ & $3,0: 1,0$ & $3,2: 1,0$ & $1,8: 1,0$ \\
\hline 6. & Energi (MJME/kg) & 10,2 & 10,2 & 10,2 & 10,1 \\
\hline
\end{tabular}

\section{Analisa Statistik}

Data hasil penelitian dianalisa secara statistik melalui analisa keragaman (variance analysis) dengan menggunakan Rancangan Acak Lengkap yang terdiri atas 4 perlakuan (ransum) dan 10 ulangan. Sedangkan untuk bobot dan persentase karkas terdiri atas 5 ulangan. Untuk mengetahui tingkat perbedaan nilai rataan antar perlakuan dilakukan Uji Jarak Duncan (DMRT) (Steel and Torrie, 1981)

\section{Analisa Ekonomi}

Untuk membandingkan perlakuan secara ekonomis, data penerimaan dan pengeluaran dianalisa melalui analisa gross margin (gross margin analysis) (Khalil dkk, 2001).

\section{Hasil Dan Pembahasan}

\section{Performan Secara Biologis}

Pada Tabel 2 disajikan data rataan bobot badan, pertambahan bobot badan, konsumsi dan konversi ransum serta bobot dan persentase karkas. Ayam yang mendapat ransum mengandung cangkang siput yang dibakar menunjukkan angka tertinggi pada bobot badan akhir, laju pertambahan bobot badan harian, konsumsi dan bobot karkas. Bobot badan akhir berkisar antara 1027,6 1229,6 g/ekor. Bobot badan akhir 
ayam yang mendapat ransum mengandung cangkang siput bakar secara statistik tidak menunjukkan perbedaan yang nyata $(\mathrm{P}>0,05)$ dengan ayam yang mendapat ransum dengan sumber mineral cangkang siput berbentuk grit dan tepung mentah.

Seperti terlihat pada Gambar 1, ayam buras yang mendapat ransum dengan sumber mineral cangkang siput berbentuk grit mentah menunjukkan perkembangan bobot badan yang cepat mulai pada minggu ke-2 sampai minggu ke-9, jika dibandingkan dengan ayam pada perlakukan lainnya. Akan tetapi, setelah minggu ke-10 sampai minggu ke-12 ternyata ayam yang mendapat ransum dengan sumber mineral tepung cangkang siput yang dibakar lebih tinggi bobot badannya.

Pada Tabel 2 terlihat bahwa laju pertambahan bobot badan ayam selama 12 minggu pemeliharaan berkisar antara 7,4-9,4 g/rkor/hari. Pertambahan bobot badan tertinggi ditunjukkan oleh ayam yang mendapat ransum mengandung cangkang siput yang dibakar, sedangkan yang terendah pada ayam yang mendapat ransum dengan sumber mineral kulit kerang. Laju pertumbuhan yang tinggi ini memberikan dampak positif terhadap bobot karkas, dimana bobot karkas tertinggi $(\mathrm{P}<0,05)$ terlihat pada ayam yang mendapat ransum yang menggunakan cangkang siput bakar sebagai sumber mineral (816 g/ekor).

Tabel 2. Rataan Pertambahan Bobot Badan, Konsumsi Dan Konversi Ransum Ayam Buras Yang Diberi Ransum Dengan Sumber Mineral Berbeda Selama Penelitian

\begin{tabular}{|c|c|c|c|c|c|}
\hline \multirow{5}{*}{ No. } & \multirow{5}{*}{ Parameter } & \multicolumn{4}{|c|}{ Ransum Perlakuan Dengan Sumber Mineral: } \\
\hline & & Cangkang & Tepung & Tepung & Tepung \\
\hline & & Siput Grit & Cangkang & Cangkang & Kulit \\
\hline & & Mentah & Siput & Siput & Kerang \\
\hline & & & Mentah & Bakar & \\
\hline \multirow[t]{2}{*}{1.} & Bobot badan & $450,4^{a}$ & $412,3^{a}$ & $439,9^{a}$ & $406,7^{\mathrm{a}}$ \\
\hline & (g/ekor) & $(18,6)$ & $(19,5)$ & $(11,5)$ & $(19,5)$ \\
\hline \multirow[t]{2}{*}{2.} & Bobot badan & $1215,6^{\mathrm{a}}$ & $1174,5^{\mathrm{ab}}$ & $1229,6^{a}$ & $1027,6^{b}$ \\
\hline & (g/ekor) & $(2,4)$ & $(17,2)$ & $(1,9)$ & $(21,6)$ \\
\hline \multirow[t]{2}{*}{3.} & Pertambahan & $9,1^{\text {ab }}$ & $8,7^{b c}$ & $9,4^{a b}$ & $7,4^{\mathrm{c}}$ \\
\hline & badan harian (g/ekor) & $(11,1)$ & $(17,4)$ & $(7,6)$ & $(35,7)$ \\
\hline \multirow[t]{2}{*}{4.} & Konsumsi ransum total & $7819,3^{b}$ & $7886,8^{b}$ & $8829,0^{\text {a }}$ & $7165,7^{\mathrm{c}}$ \\
\hline & (g/ekor) & $(15,7)$ & $(10,6)$ & $(9,3)$ & $(21,7)$ \\
\hline \multirow[t]{2}{*}{5.} & Konsumsi & $93,1^{\text {ab }}$ & $93,9^{\text {ab }}$ & $105,1^{\text {a }}$ & $85,3^{b}$ \\
\hline & harian (g/ekor) & $(15,7)$ & $(10,6)$ & $(9,4)$ & $(21,7)$ \\
\hline \multirow[t]{2}{*}{6.} & Konversi ransum & $10,2^{a}$ & $11,6^{\mathrm{a}}$ & $11,3^{\mathrm{a}}$ & $18,9^{\text {a }}$ \\
\hline & & $(13,0)$ & $(28,9)$ & $(12,8)$ & $(131,2)$ \\
\hline \multirow[t]{2}{*}{7.} & Bobot karkas (g/ekor) & $808,2^{a}$ & $781,4^{b}$ & $816,4^{a}$ & $743,0^{\mathrm{c}}$ \\
\hline & & $(0,3)$ & $(0,6)$ & $(0,2)$ & $(0,6)$ \\
\hline \multirow[t]{2}{*}{8.} & Persentase karkas (\%) & $67,1^{\mathrm{a}}$ & $67,1^{a}$ & $67,2^{a}$ & $67,1^{\mathrm{a}}$ \\
\hline & & $(0,1)$ & $(0,1)$ & $(0,1)$ & $(0,1)$ \\
\hline
\end{tabular}

Keterangan: - Nilai dengan superskrip berbeda pada baris yang sama menunjukkan perbedaan yang nyata $(\mathrm{P}<0,05)$,

- Angka dalam kurung yang dicetak miring adalah nilai koefsien keragaman (coefisien variation) dalam \%) 


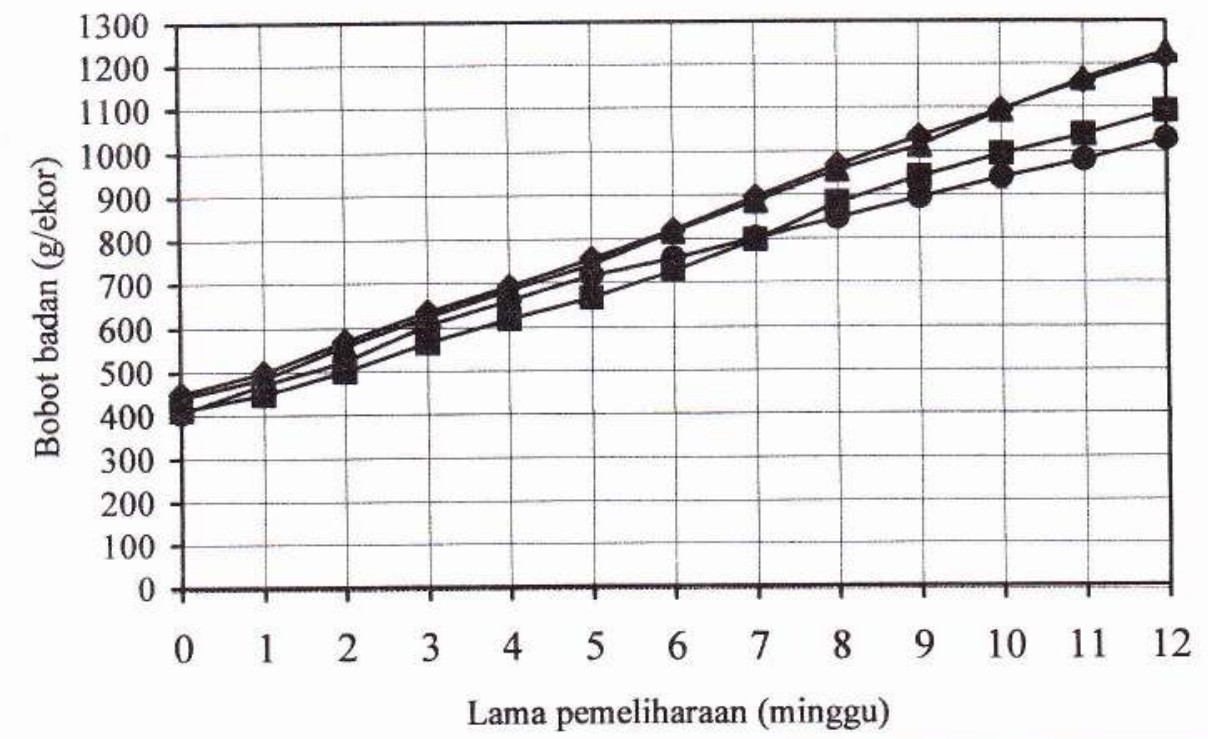

\begin{tabular}{ll}
$\longrightarrow$ - Cangkang siput grit & - Tepung cangkang siput mentah \\
$\rightarrow$ - Tepung cangkang siput bakar & - Kulit kerang \\
\hline
\end{tabular}

Gambar 1. Perkembangan Bobot Badan Ayam Selama Penelitian

Tabel 3. Analisis Gross Margin untuk Semua Perlakuan Yang Diurut Dari Penerimaan Bersih Terendah Sampai Tertinggi (Rp/Ekor)

\begin{tabular}{|c|c|c|c|c|}
\hline \multirow[b]{2}{*}{ Ura i a n } & \multicolumn{4}{|c|}{ Ransum Perlakuan Dengan Sumber Mineral } \\
\hline & $\begin{array}{c}\text { Kulit } \\
\text { Kerang } \\
\text { (Rp/ekor) }\end{array}$ & $\begin{array}{l}\text { Cangkang } \\
\text { Siput Grit } \\
\text { Mentah } \\
\text { (Rp/ekor) }\end{array}$ & $\begin{array}{c}\text { Tepung } \\
\text { Cangkang } \\
\text { Siput Mentah } \\
\text { (Rp/ekor) }\end{array}$ & $\begin{array}{c}\text { Tepung } \\
\text { Cangkang } \\
\text { Siput } \\
\text { Bakar } \\
\text { (Rp/ekor) }\end{array}$ \\
\hline \multicolumn{5}{|l|}{ Penerimaan kotor: } \\
\hline Penjualan ayam & $18.540,0$ & $21.960,0$ & $19.620,0$ & $22.140,0$ \\
\hline Penjualan kotoran & 860,0 & 850,0 & 800,0 & 970,0 \\
\hline Total penerimaan kotor & $19.400,0$ & $22.810,0$ & $20.420,0$ & $23.110,0$ \\
\hline \multicolumn{5}{|l|}{ Biaya variabel: } \\
\hline $\begin{array}{l}\text { 1. Biaya ransum } \\
\text { 2. Biaya air dan listrik } \\
\text { 3. Biaya bibit } \\
\text { 4. Biaya obat }\end{array}$ & $\begin{array}{c}9.424,8 \\
2.398,8 \\
5.740,0 \\
250,0\end{array}$ & $\begin{array}{r}11.118,9 \\
2.407,3 \\
6.300,0 \\
250,0\end{array}$ & $\begin{array}{r}11.764,7 \\
2.409,6 \\
5.740,0 \\
250,0\end{array}$ & $\begin{array}{r}13.745,6 \\
2.408,7 \\
6.160,0 \\
250,0\end{array}$ \\
\hline Sub-total biaya variabel: & $17.813,6$ & $20.076,2$ & $20.164,3$ & $22.564,3$ \\
\hline 5. Biaya modal & 534,4 & 602,3 & 604,9 & 676,9 \\
\hline Total biaya varibel: & $18.348,0$ & $20.678,5$ & $20.769,2$ & $23.241,2$ \\
\hline Penerimaan bersih: & $1.052,0$ & $2.131,5$ & $-349,2$ & $-131,0$ \\
\hline
\end{tabular}


Tingginya laju pertambahan bobot badan pada ayam yang mendapat ransum yang mengandung cangkang siput bakar terutama disebabkan oleh tingginya konsumsi ransum. Seperti terlihat pada Tabel 2, total konsumsi ransum selama penelitian berkisar antara 7166 - 8829 g/ekor, sedang konsumsi harian berkisar antara $85-105$ g/ekor. Secara angka, konsumsi ransum tertinggi ditunjukkan oleh ayam yang mendapat ransum yang mengandung cangkang siput bakat, secara statistik tidak berbeda nyata dengan konsumsi ransum pada ayam yang mendapat ransum mengandung cangkang siput dalam bentuk grit dan tepung mentah, tetapi nyata lebih tinggi $(\mathrm{P}<0,05)$ daripada konsumsi pada ayam yang mendapat ransum mengandung kulit kerang.

\section{Performan Secara Ekonomis}

Pada Tabel 3 disajikan data hasil analisis gross margin yang diurut dari biaya variabel terendah ke tertinggi. Biaya variabel terendah ( Rp 18.348 /ekor) ditunjukkan oleh ayam yang mendapat ransum perlakuan dengan sumber mineral kulit kerang, dengan penerimaan bersih terendah, sebesar $\mathrm{Rp}$ 1.052/ekor. Penerimaan bersih

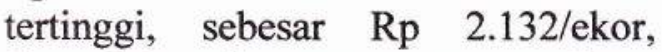
diperoleh pada ayam yang mendapat ransum dengan sumber utama mineral cangkang siput dalam bentuk grit. Sedangkan ayam yang diberi perlakuan ransum dengan sumber utama mineral berupa cangkang siput dalam bentuk tepung mentah dan bakar memberikan penerimaan bersih yang negatif.

Pada setiap perlakukan terlihat bahwa biaya ransum merupakan biaya yang terbesar dari seluruh biaya variabel. Penerimaan kotor tertinggi, sebesar Rp 23.110/ekor ditunjukan oleh ayam yang mendapat ransum mengandung cangkang siput bakar. Akan tetapi biaya ransum yang tinggi, mencapai Rp 13.746/ekor menyebabkan biaya produksi meningkat, sehinga melebihi penerimaan kotor. Tingginya biaya ransum ini terutama disebabkan oleh tingginya jumlah konsumsi ransum (Tabel 2) dan biaya pengolahan (proses pembakaran) cangkang dalam skala kecil.

\section{Kesimpulan}

Dari hasil penelitian dapat disimpulkan bahwa proses pembakaran cangkang siput sebelum digunakan dalam ransum ayam buras periode grower ternyata dapat meningkatkan nilai nutrisi ransum, yang dilihat dari aspek laju pertumbuhan, konsumsi ransum dan bobot karkas, tetapi secara ekonomi kurang menguntungkan, karena tingginya biaya produksi, terutama biaya pakan. Dari aspek ekonomi, ternyata penggunaan cangkang siput dalam bentuk grit mentah ayang lebih menguntungkan, karena menghasilkan penerimaan bersih tertinggi.

\section{Daftar Pustaka}

Iskandar, S., E. Juarini. D. Zainuddin, H. Resnawati, H. Wibowo dan Sumanto, 1991. Teknologi Tepat Guna Ayam Buras. BPT, Ciawi, Bogor.

Khalil, 2003. Analisa rendemen dan kandungan mineral cangkang pensi dan siput dari berbagai habitat air tawar di Sumatera Barat. J. Peternalan dan Lingkungan, vol. 09 (3):35-41.

Khalil, 2004. Evaluasi nilai nutrisi cangkang siput sebagai sumber mineral pada ransum anak ayam buras. J. Peternakan dan 
Lingkungan. (Dalam proses Steel, R.G.D. Torrie, J.H., 1981. penerbitan).

Principles and Procedures of Statistics. McGraw-Hill International Book Company, Auckland.

Peningkatan Efisiensi Pemecontoh penerapan analisis ekonomi dalam penelitian bidang pakan dan nutrisi. Media Peternakan, 24 (1):45-50.

Nawawi, N.T. dan S. Nurrohmah, 2002. Ransum Ayam Kampung. Trubus Agrisarana. Surabaya.

Tillman, A.D.H., S. Hartadi., R. Hadiprojo dan S. Lepdosoekojo, 1998. Ilmu Nutrisi dan Makanan Ternak. Gajah Mada University Press, Yogjakarta.

Alamat Korespondensi: Dr. Ir. Khalil, M.Sc

Simpang Kototinggi, Pandai Sikek

Padang Panjang 27151

SUMBAR

Tel/Fax: 0752/498162

Email: khalil@faterna.unand.co.id 